\title{
伝統の箔製造技術が手中 におさめた携帯電話市場
}

\section{Ancient foil maker wraps up mobile-phone market}

Nature Vol.436(775)/11 August 2005 冬野いち子

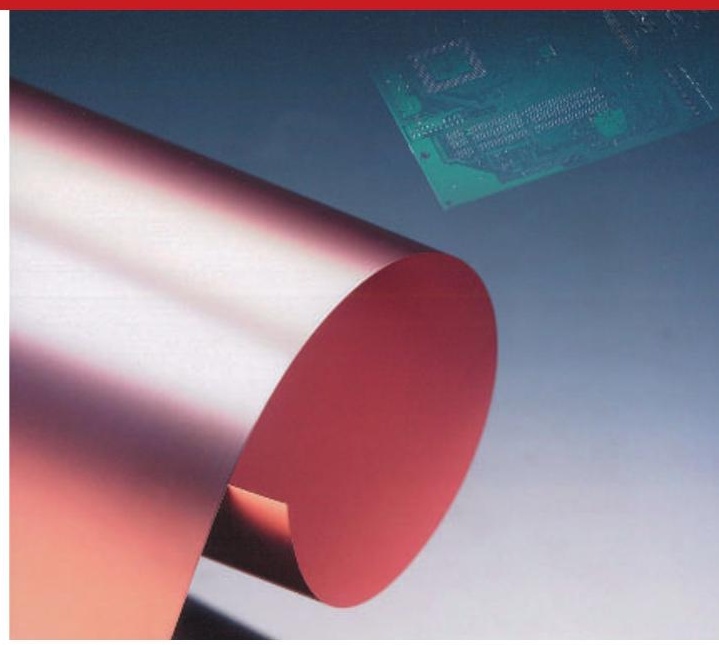

1980 年頃までの技術を基盤とするハ イテク企業は、ほとんど存在しない。 ましてや、今から 305 年前に作りだ された伝統工芸なんて役に立つはず がないと思われていた。ところが、 17 世紀末以来順調に事業を展開して きた日本の同族会社が、この 8 月に、 金属箔粉事業で日本政府から賞を受 けた。今日、金属箔の最終用途は、 ほとんどが携帯電話なのである。

福田金属箔粉工業が 1700 年に京 都で創業したとき、その事業内容は、 豪華な屏風や陶器に金箔や銀箔の複 雑な柄をつけるという、今日にも通 ずるものであった。その後、同社は、 技術の進歩や市場の变化を注視する ことで、急成長する携帯電話産業向 けの銅箔ロールで世界をリードする サプライヤーとなった。

「福田金属箔粉工業は、長い歴史を もっているが、（特筆すべきことは） むしろ同時に、技術や経営で独自の領 域を拓いていったことだ」。こう語る のは、京都に近い立命館大学の経済 学部教授で同社をよく知る長島修だ。

未公開会社の福田金属箔粉工業の 昨年の売上高は 360 億円に達し、現 在の従業員数は約 1,000 人。事業拠 点は、主に京都と蘇州（中国）に集 中している。同社では、1,000 種類 の金属粉、200 種類の箔など多種多 様な金属製品を製造している。これ
らの製品は、自動車部品から食品包 装にいたるさまざまな製品に使われ ている。その中で、おそらく最もめ ざましい成功をおさめていると思わ れるのが携帯電話用銅箔部品の世界 市場で、同社は、40\%のシェアを誇つ ているという。

去る8月4日、福田金属箔粉工業は、 その卓越した技能、そして伝統技術 を情報時代に見事に融合させたこと に対して賞を受け、小泉純一郎首相 から賞状などを受け取った。

「売れると思った製品が実際に売れ るとは限らない。むしろ、意図しない で拡大しているものが多い。研究・技 術基盤があったからこそ、我が社の製 品は、新たな要望に応えることができ た」。林泰彦社長は、こう語った。

もともと化学エンジニアだった林 社長は、同社に入社するまでは金属 粉に興味をもっていたが、入社後は ほぼ銅䇴一筋の会社人生となり、銅 箔を手に取って振るだけで、その品 質を判定する技能を身につけるまで になった。今、ようやく新種の金属 粉の発明という夢の実現に取り組め るようになった、と林社長はいう。

金属粉の場合、「重要なのは粒子の 大きさと形だ」と林社長は説明する。 彼の会社では、金属粉の粒径を約 $1 \sim 250$ ミクロンの範囲内で調整で きる。サイズや形状を少し変えるだ
けでも、金属粉の特性に大きな影響 が出る。たとえば、金属粉が圧縮され、 加熱されたときに粒子同士が接着す るかどうかという特性である。

福田金属箔粉工業の研究者とエン ジニアには、年間約 8 億円の研究開 発予算が与えられており、日本全国 の大学や研究機関と共同研究を行っ ている。たとえば、京都大学で表面 光化学を研究する川崎三津夫助教授 とは、最近、銅合金を使って、直系 0.1 ミクロン未満のナノスケール微粒 子を作りだした。この場合、粒子を 有機溶媒に入れておいて、レーザー で照射し粉砕するという製法が用い られた。

今後の懸念事項の 1 つとして、同 社の上層部たちは、日本の大企業と の技術者の奪い合いを挙げる。また、 中国や韓国、台湾の企業との競争も 激しくなってきている。将来、成長 を続けるためには、燃料電池のよう な新規市場を精力的に開拓するとと もに製品開発の加速が重要になると、 林社長はみている。「我が社は組織的 にマンネリ化してきた。新しいモノを 生みださなくては」と同社長はいう。

冬野いち子は Nature のアジア・パシフィック 担当記者。 